UNITED STATES DEPARTMENT OF THE INTERIOR

J. A. Krug, Secretary

GEOLOGICAL SURVEY

W. E. Wrather, Director

Bulletin 947-F

\title{
COPPER DEPOSITS OF THE NIZINA DISTRICT, ALASKA
}

\author{
BY \\ DON J. MILLER \\ WITH:AN INTRODUCTION BY \\ FRED H. MOFFIT
}

Mineral resources of Alaska, 1943 and 1944

(Pages_93-120)

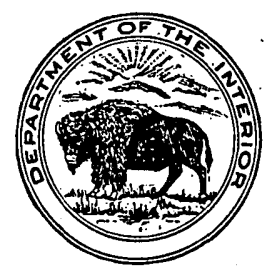

UNITED STATES

GOVERNMENT PRINTING OFFICE

WASHINGTON : 1946

For sale by the Superintendent of Documents, U. S. Government Printing Office, Washington 25, D, $\boldsymbol{C}_{\text {, }}$ Price 15 cents 



\section{CONTENTS}

Introduction, Copper deposits of the Chitina Valley, by Fred H. Moffit...-

Abstract_....

Geography -...2

Geology

Copper deposits

Kennecott mines.

Regal mine.

Green Butte mine. .

Tjosevig prospect._. 104

Nikolai mine_._.

Westover prospect._. . .

Nelson prospect. - . . .

Radovan prospect. .

Erickson prospect. . . . .

Other prospects. . . . . .

Hidden Creek and Fourth of July Creek

Dan Creek................ 119

Chitistone River............ 120

\section{ILLUSTRATIONS}

Plate 26. Sketch map showing location of copper deposits of the Nizina district. . . -

27. Sketch map of the Green Butte and Tjosevig patented claims...

28. Generalized map of underground workings of the Green Butte mine . . . . In pocket

29. Sketch map showing geology of underground workings at the Westover prospect and geology of the adjacent area.- In pocket

Figure 12. Index map of part of Alaska showing the location of the Nizina district. . . .

13. Sketch map of the Regal mine, showing accessible underground workings (1943) and geology of the adjacent area.-

14. Sketch map of the Nikolai patented claims..............

15. Map of underground workings of the Nikolai mine, showing geology of the adjacent area. . . . .

16. Geologic sketch map of the vicinity of the Nelson and Radovan copper prospects. . .

17. Map of underground workings at the Nelson prospect, show-

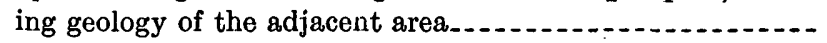

18. Map of patented claims at the Erickson prospect.........

19. Sketch map of tunnel No. 2, Erickson prospect............... 



\title{
INTRODUCTION
}

\section{COPPER DEPOSITS OF THE CHITINA VALLEY}

\author{
By Fred H. MOERTX
}

Copper was known in the Copper River region, which includes the Chitina Valley, from the days of the early Russian exploration along the Pacific Coast of Alaska, but it was not the object of special search until the time of the gold stampede in 1898. Exploration in the Copper River drainage basin begun in that year led to the discovery in 1900 of the Bonanza ore body of the Kennecott mines and to many other mines and prospects throughout the area.

In early days the principal route of approach to the mining camps of the Chitina Valley was a branch of the military trail from Valdez to Eagle on the Yukon River. This branch left the Eagle Trail, now in part the Richardson Highway, at Upper Tonsina, crossed the Copper River a short distance above the mouth of the Tonsina River, and skirted the south slopes of the Wrangell Mountains. This was the trail commonly used in summer; travel shifted to the ice of the Tonsina, Copper, and Chitina Rivers in winter. After the completion of the Copper River \& Northwestern Railroad in 1911 the trail through the Chitina Valley was practically deserted, and transportation was by rail, supplemented to a certain extent by the airplane, until 1938, when operations at the Kennecott mines ended and the railroad was abandoned. At present (1943) the usual route of travel to points in the Chitina Valley is the Richardson Highway and one of its branches leading to the town of Chitina on the west side of the Copper River opposite the mouth of the Chitina River. At Chitina it is necessary to use a boat or an aerial tram to cross the Copper River, for the railroad bridge is washed out. East of the river the tracks of the railroad are still in place and are used for hauling freight and passengers by gas-driven motor car, although not without difficulties caused by landslides and especially by the washing out of the Kennicott River bridge in 1943.

The copper-bearing rocks of the Chitina Valley are exposed for the most part on the north side of the valley, in the south slopes of the Wrangell Mountains, and they extend eastward from the Kotsina River to Glacier and Young Creeks, a distance of approximately 75 
miles. The rocks of the copper belt are mostly bedded, this term being used to include lava flows as well as sedimentary beds. The oldest known rocks, those of the Strelna formation of Mississippian age, consist chiefly of schist and slate, locally associated with altered limestone, tuffaceous beds, and lava flows. They are not of particular importance in connection with the copper deposits, although copper minerals have been found in them. They are overlain, probably unconformably, by a great thickness, at least 5,000 feet, of basaltic lavas long known as the Nikolai greenstone. The Nikolai greenstone is in part, if not wholly, of Permian age and is overlain with structural conformity so far as is known, by the Chitistone and Nizina limestones of Upper Triassic age. The limestone formations are approximately 3,000 feet thick. The Nikolai greenstone and the Chitistone limestone are the host rocks of all the best-known copper deposits. They are overlain by Jurassic and Cretaceous sedimentary rocks, including shale, sandstone, and conglomerate, which for the purposes of this report need no further description. All the bedded rocks have been folded, faulted, and intruded by igneous rocks of different types and ages. The general geology of the region has been described elsewhere by the writer. ${ }^{1}$.

Copper and copper-bearing minerals commonly associated with one or more sulfides of other metals have been found in many places in the Nikolai greenstone, but all the known large deposits were in the lower part of the Chitistone limestone. The deposits are distributed in two principal districts, the Kotsina-Kuskulana on the west and the Nizina on the east, and are separated by an area in which evidences of copper are less common.

Most of the copper mines and prospects in the Nizina district were visited by Mr. Miller in 1943, between June 19 and August 29, the principal objective being to obtain information on the status of the copper deposits at that time.

\footnotetext{
romt, F. H., Geology of the Chitina Valley and adjacent area, Alaska: U. \$. Geol.
Survey Bull. 894, 1988.
} 


\title{
COPPER DEPOSITS OF THE NIZINA DISTRICT, ALASKA
}

\author{
By Don J. Miller
}

\begin{abstract}
The Nizina district lies on the southeast flank of the Wrangell Mountains, about 60 miles east of Chitina and about 200 miles by automobile road and rail from the port of Valdez. The first copper claims were located in 1899. From 1911 to 1938 the district produced more than a billion pounds of copper, nearly all from the Kennecott mines. When the Kennecott mines closed and the railroad to Cordova was abandoned, in 1938, copper production ceased, except for a few tons of copper nuggets recovered as a byproduct of gold-placer operations.

The bost rocks of the copper deposits are the Nikolai greenstone, consisting of altered basaltic lava flows of Permian and Triassic (?) age, and the overlying Chitistone limestone, consisting of massive thick-bedded limestone of Upper Triassic age: The greenstone and limestone are folded into a broad syncline trending northwest. The deposition of the ore bodies was controlled in part by minor cross folds, steeply dipping faults that strike at a large angle to the axis of the major fold, and bedding faults.

Chalcocite is the principal copper mineral in most of the deposits in limestone, and bornite and chalcocite are the principal copper minerals in the deposits in greenstone. Native copper also occurs in the greenstone. Nearly all the ore has come from the lowest 300 feet of the Chitistone limestone.

In this report 7 mines and about 13 prospects, comprising nearly all of the know'n copper deposits of the district, are described briefly. None of the known deposits is believed to offer sufficient promise of significant production or profit to warrant the cost of reestablishing a practicable means of transportation to the district solely for the copper.
\end{abstract}

\section{GEOGRAPHY}

The Nizina district (see fig. 12) is on the southeast flank of the Wrangell Mountains, a rugged range with several peaks higher than 12,000 feet. Most of the known copper deposits are in the part of the district shown on plate 26 . In this area the relief in places exceeds 5,000 feet. The rugged mountains in the eastern and northern parts of the area contrast strongly with the broad, swampy lowland along the Nizina River in the southwestern part. The highest peaks, more than 8,000 feet, are between Dan Creek and Glacier Creek. All of the area except the highest peaks and ridges has been glaciated, and glaciers still exist in several valleys and on the ridge between Dan and Glacier Creeks. 


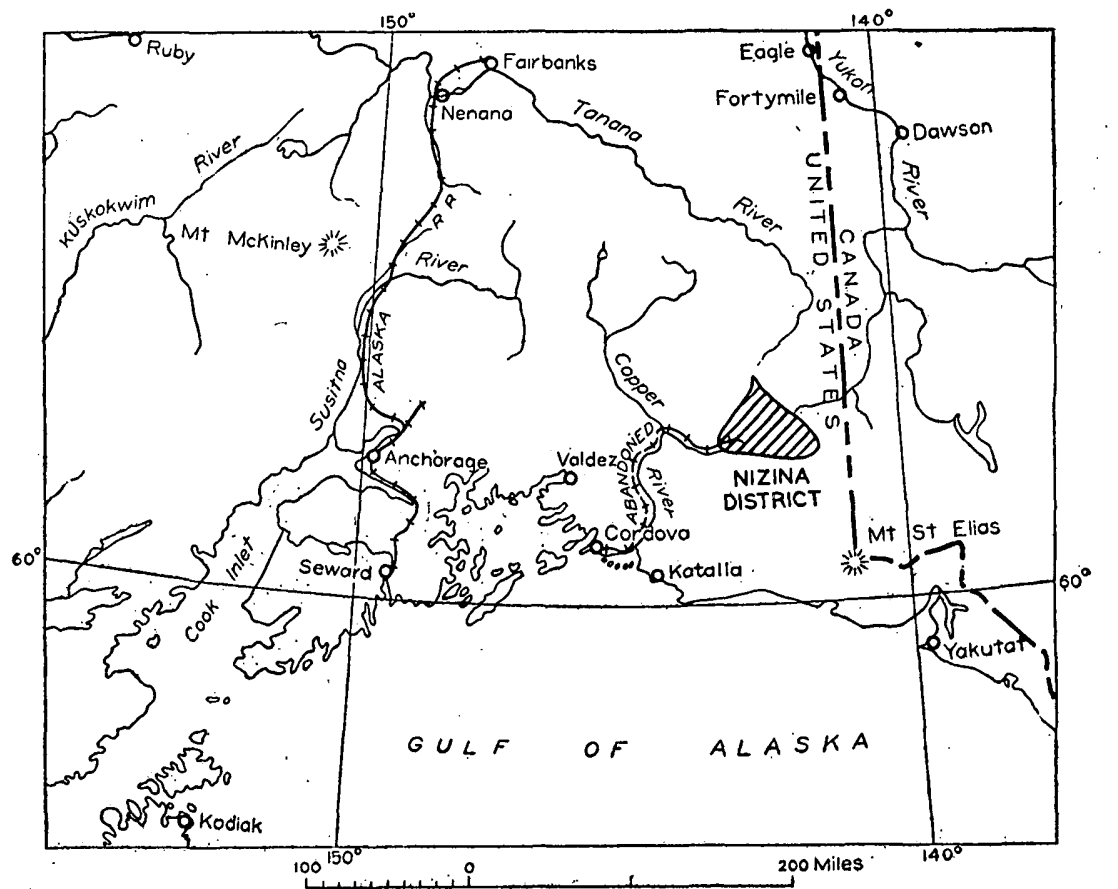

Figure 12.-Index map of part of Alaska showing the location of the Nizina district.

Most of the large streams in the Nizina district head in glaciers, consequently their volume is subject to wide daily and seasonal variations. The gradient of the streams is steep, and the current is swift. Nizina River and its major tributaries, Kennicott River and Chitistone River, are obstacles to travel during the summer. During high water, even the larger creeks, such as McCarthy, Young, and Glacier Creeks, can be crossed only at favorable places.

McCarthy, Kennecott, and the placer camps on Dan Creek and Chititu Creek are the only settlements in the Nizina district. Most of the permanent inhabitants, totaling perhaps a dozen, live at McCarthy. Roads and trails formerly led from McCarthy to outlying parts of the district, but many of the trails have not been used in recent years and are difficult to follow or impassable. A short automobile road leads from McCarthy to Kennecott, and a longer road connects McCarthy with the gold-placer camps on Dan Creek and Chititu Creek. Part of the Nizina River bridge on the longer road is washed out, necessitating the use of short hand-powered aerial tramways during part of the summer of 1943. A trail, formerly an automobile road, follows McCarthy Creek to a point east of the Mother Lode mine, a distance of 13 miles. Some of the bridges are washed out, and some of the remaining bridges are not safe for horses, but.in 1943 the trail could be traveled on foot at any time, or on horseback when 
McCarthy Creek was low enough to ford. A wagon road that formerly extended from the Dan Creek road over the flood plains of the Nizina and the Chitistone Rivers to Glacier Creek has been partly destroyed by changes in the course of the Chitistone River. The route on the east side of the Nizina River and the south side of the Chitistone River can still be followed on foot, but with horses it is necessary to cross the Chitistone River several times between its mouth and Glacier Creek.

\section{GEOLOGY}

The geology of the Nizina district has been described by Moffit and Capps. $^{2}$ All of the rocks of the Chitina Valley copper belt (see p. 93), except the Strelna formation, are exposed in the Nizina district. The host rocks of the copper deposits are the Nikolai greenstone and the Chitistone limestone.

The Nikolai greenstone, of Permian and Triassic(?) age, consists in the Nizina district of a thick succession of altered basaltic lava flows which commonly are dark green but locally are red or reddish brown. Most of the flows are coarse-textured and many are amygdaloidal. The greenstone commonly appears massive in outcrop, for its bedded character is not readily apparent except at a few places.

The Chitistone limestone, of Upper Triassic age, overlies the Nikolai greenstone with apparent conformity. A thin bed of bluish-gray, green, or reddish-brown shale separates the limestone and greenstone at most places. The Chitistone limestone consists chiefly of massive limestone, bluish gray on fresh surfaces and light gray on weathered surfaces. Locally some of the beds are dolomitic. The thickest beds are in the lower part of the formation; toward the top the beds thin, and the formation grades almost imperceptibly into the overlying thin-bedded Nizina limestone.

The major structure involving the Nikolai greenstone and Chitistone limestone in the Nizina district is a broad syncline whose axis trends slightly west of northwest and plunges northwest. The axis lies midway between Glacier and Dan Creeks and crosses the Nizina River about 2 miles north of its junction with the Chitistone River. This major fold is complicated by minor cross folds and by faults of three types: (1) Faults of large displacement, which strike nearly parallel to the axis of the major fold and dip at a low angle; (2) steeply dipping faults of small to moderate displacement, which commonly strike at a large angle to the axis of the major fold; and (3) faults of small to moderate displacement along contact or bedding

\footnotetext{
${ }^{2}$ Moffit, F. H., and Capps, S. R., Geology and mineral resources of the Nizina district, Alaska : U. S. Geol. Survey Bull. 448, 1911.
}

$689321-46-2$ 
planes. The minor cross folds and faults of the second and third types played an important part in localizing the copper deposits.

\section{COPPER DEPOSITS}

The period of active prospecting for copper and development of copper mines in the Nizina district began in 1900 with the exploratory work on the Nikolai mine and the discovery of the Bonanza ore body, and it ended with the closing of the Kennecott mines in 1938. From 1911 to 1938 the district produced more than a billion pounds of copper, nearly all from the Kennecott mines. The copper production since 1938 has been only a few tons of nuggets, which were shipped to the smelter in the winter of 1943-44. The district has also produced silver, mostly as a byproduct of copper ore, and gold from placer deposits, but the total value of these metals is far less than that of the copper.

The copper-lode deposits in the Nizina district may be classified according to the nature of the host rock and the principal sulfide and gangue minerals. The Bonanza, Jumbo, Erie, Mother Lode, Green Butte, and Nelson deposits are in Chitistone limestone; chalcocite is the principal sulfide mineral, and calcite and dolomite are the only gangue minerals. The Westover and Radovan deposits also are in Chitistone limestone but differ in that bornite in the first and pyrite in the second are more abundant than chalcocite; in both quartz is a prominent gangue mineral. The Nikolai deposit and other deposits on Dan, Hidden, and Fourth of July Creeks are in Nikolai greenstone; in these deposits bornite and chalcopyrite are the principal sulfide minerals. In the Erickson deposit; which is also in Nikolai greenstone, the copper occurs chiefly as native copper and copper oxides. The nuggets of native copper found on Dan, Chititu, and Young Creeks and on some of their tributaries were derived from the greenstone.

A theory of origin which seems best to fit the Nizina copper deposits was suggested by Moffit and Capps ${ }^{3}$ as a result of a study of the general geology of this district, and developed in greater detail by Bateman and McLaughlin ${ }^{4}$ as a result of an intensive study of the ore deposits at the Kennecott mines. The source of the copper is believed to be the Nikolai greenstone, which everywhere contains a small amount of copper, probably as a primary constituent. After deposition of the Chitistone limestone, part of the copper was leached out of the greenstone by heated meteoric water and redeposited in favor-

s Moffit, F. H., and Capps, S. R., Geology and mineral resources of the Nizina district, Alaska : U. S. Geol. Survey Bull. 448, pp. 81-83, 1911.

Bateman, A. M., and McLaughlin, D. H., Geologg of the ore deposits of Kennecott, Alaska : Econ. Geolngy, vol. 15, No. 1, pp. 77-80, 1920. 
able places in both the greenstone and the limestone. The limestone, containing larger and more continuous fractures and being more easily replaced, became host to larger and richer deposits than the greenstone.

None of the known copper deposits in the Nizina district is believed to offer sufficient promise of significant production or profit to warrant the cost of reestablishing a practicable means of transprortation to the district solely for the copper. If in the future such means of transportation is established for general development of the district, then it is likely that some of the known deposits could be operated protitably and that other deposits, perhaps larger, might be found.

\section{KENNECOTT MINES}

The mines of the Kennecott Copper Corp. at Kennecott were in almost continuous operation from 1911 to 1938 and yielded much the larger part of the copper obtained from Alaska during those years. When thorough exploration by extensive underground openings and many: thousands of feet of diamond-drill holes had failed to reveal new ore bodies the mines were closed, in 1938. Since then no lode copper has been produced in the Chitina Valley.

The properties include the Bonanza, Jumbo, and Erie mines of the Kennecott Copper Corp., and the Mother Lode mine of the subsidiary Mother Lode Coalition Mines Co., situated at altitudes ranging from 4,000 to 6,000 feet in the mountains between Root Glacier and McCarthy Creek. (See pl. 26.) Much of the extensive mining equipment is still in place. The mill, power plant, and other company buildings are at Kennecott, several miles from the mines. Two aerial tramways, each about 3 miles long, extend from the mill to the $\mathrm{Bo}$ nanza mine and the Jumbo mine. These tramways gave access to all the mines, which are connected underground. At. present the only means of access is by trails from Kennecott to the Bonanza, Jumbo, and Erie mines, and from the McCarthy Creek trail to the Mother Lode mine. These trails have been little used in recent years and parts of them are difficult to follow.

The large body of chalcocite which was the outcrop of the Bonanza ore body was discovered in 1900. About 1905 the Bonanza claims and other claims in the vicinity were consolidated under the ownership of the Kennecott Copper Corp. Shipments of ore from the Bonanza mine began in April 1911, when the railroad from Cordova was completed. The Jumbo mine began production in 1913, the Erie mine in 1916.

Some of the claims east of the divide between McCarthy Creek and Root Glacier were first developed by the Mother Lode Co. This company made small shipments of ore from the Mother Lode mine each 
winter from 1913 to 1918 , tramming the ore to McCarthy Creek and hauling it down the creek to the railroad. In 1919 the Mother Lode mine became the pioperty of the Mother Eode Coalition Mines Co. and thereafter was operated as a unit with the other Kennecott mines; the Mother Lode ore was then hoisted through the Bonanza mine and trammed to the mill at Kennecott.

The Mother Lode mine was closed in July 1938, and the other Kennecott mines in October 1938. Operation of the railroad ceased in November of the sane year, after the equipment that could be profitably salvaged had been reinoved.

The underground workings of the 4 mines probably have a total length of several huzdred miles. 'The deepest workings are in the Mother Lode mine where the main incline extends to the 2,800-foot level on the lower pait of the Bonanza ore body. The Bonanza mine is connected with tha Jumbo mine by a tunnel about three-quarters of a mile long, and the Jumbo mine is connected with the Erie mine by a turnel more than 2 miles long. Little timbering was necessary in the mining operations, and the underground workings will probably reriain open for a long time, except in large stopes and where ice forms.

The ore bodies were in the Chitistone limestone slightly above the greenstone-limestone contact, which is exposed almost continuously from Root Glacier, near the Erie mine, to McCarthy Creek, southeast of the Mother Lode mine. The linestone and greenstone strike northwest and $\operatorname{dip} 23^{\circ}-30^{\circ} \mathrm{NE}$. The ore occurred as veins, massive replacement deposits of irregular shape, and stockworks in the lower, partly dolomitic beds of the Chitistone limestone. The deposition of the principal ore bodies was controlled mainly by faults of two systems; those of one system cut the bedding of the limestone at a large angle and those of the other are parallel to the bedding. No ore was found in the greenstone, and very little ore was found above the lowest 300 feet of limestone.

Calcocite constituted about 70 percent of the ore mined. ${ }^{5}$ Malachite, azurite, and covellite were the other important copper minerals. Several other metalic minerals, constituting less than 1 percent of the ora, were found. Calcite and dolomite were the only gangue minerals. : The ore bodies were unusually large and rich, particularly those in the Bonanza and Jumbo mines. Part of the ore was shipped direct to the smelter and part was concentrated at the mill. An important economic feature of the mill practice was the recovery of fine copper carbonate ore from the tailings in the leaching plant. A considerable quantity of silver was recovered in smelting, but the ore contained almost no gold.

\footnotetext{
- Bateman, A. M., and McLaughlin, D. H., Geologs of the ore deposits of Kennecott, 'Alaska: Econ. Geology; vol. 15, No. 1, p. 35, 1920.
} 
The ore deposits at Kennecott are described in many reports by private investigators and by geologists of the Geological Survey. The mining operations are recorded in the annual reports of the Kennecott Copper Corp. and the Mother Lode Coalition Mines Co. Some of the more important reports are listed below:

Mofrit, F. H., and CAPps, S. R.; Geology and mineral sesources of the Nizina district, Alaska: U. S. Geol. Survey Bull. 448, pp. S4-93, 1911.

Moffrt, F. H., Mining in the lower Copper River Basin: U. S. Geol. \$urvey Bull. 662, pp. 163-175, 1918. Geology of the Citipa'Valley and adjacent area, Alaska: U. S. Geol. Survey Bull. 894, pp. 118-121, 1938 .

Bateman, A. M., and McLaughrin, D. H., Geology of the ore deposits of Kennecott, Alaska : Econ. Geology, vo1. 15, no. 1, pp. 1-80, $1920^{\circ}$.

BIrch, Stephen, Geology and mining methods of Kennecott mines: Am. Inst. Min. and Met. Eng. Trans. (pleprint) no. 1287, Jan. 1924; vol. 72, pp. 499-511, 1925.

LAgKY, S. G., Transverse faults at Kennecott aud their relation to the main fault systems: Am Inst. Min. Met. Eng. 'Tech. Pub. 152, 17- pp.; 1928; Trans., 1929, Yearbook, pp. 303-317.

Kennecott Copper CoRP., Annual Reports, 1915-38, New York.

Mother Lodm Coalition Mrnes Co., Annual Reports,' 1919-38, New York.

\section{REGAL MINE}

The Regal mine is between Root and IKennicott Glaciers on the southwest side of Donohoe Peak at an altitude of about 5,450 feet. (See fig. 13.) Formerly, horses could be taken from McCarthy to the mine by a route 14 miles long on the east side of Kennicott and Root Glaciers and across Root Glacier below the Erie rrine; but at present horses can go only to the crossing below the Erie mine, as the surface of Root Glacier is rough and badly cracked. Much of the trail on Donohoe Peak is grown over with brush or covered with rock slides.

The Regal group, reported to inclucle about 17 claims, was owned by a subsidiary of the Great Northern Development Co., the Regal Mines Co., which did development or assessment work on the claims from about 1910 to 1925. The claims are believed to be open for re-: staking at present. A short description of the Regal mine and the progress of development there up to 1916 is given by Moffit. ${ }^{6}$

The underground workings comprise 2 inclines, at least one of which has 1 or more levels branching from it, and 3 tumnels. (See fig. 13.) In 1943 about 760 feet of the openings was accessible. Incline No. 1 was flooded to a few feet below the first level, incline No. 2 was flooded to about 40 feet below the portal, and tunnel No. 1 was caved near the portal. Some mining equipment is left at the mine. The buildings shown on figure 13 are not habitable.

\footnotetext{
- Moffit, F. H., Mining in the lower Copper River Basin; U.'S. Geol. Survey Bull. 662, p. $163,1918$.
} 


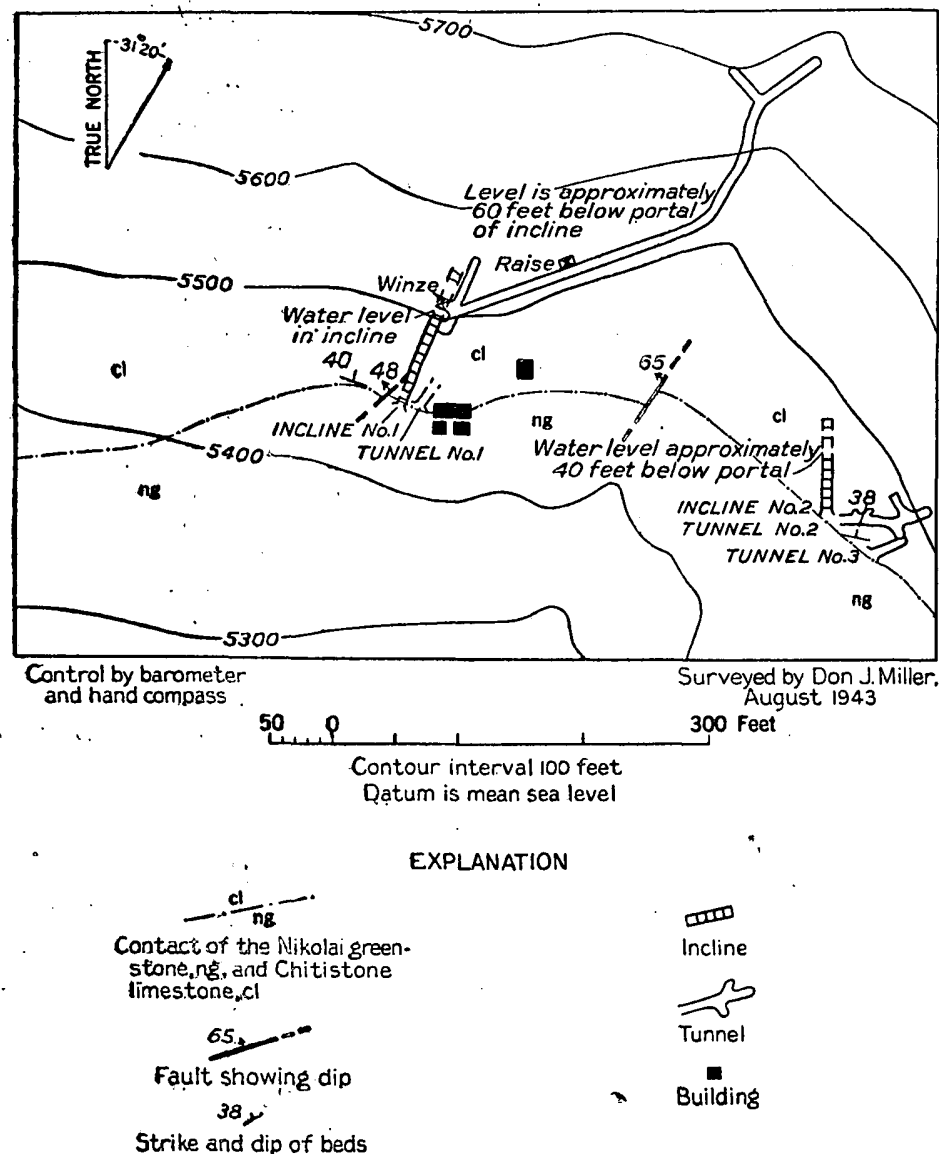

FraURE 13.-Sketch map of the Regal mine, showing accessible underground workings (1943) and geology of the adjacent area.

The Regal mine is at the contact of the Nikolai greenstone and the Chitistone limestone. The inclines follow approximately the dip of the contact, and the other openings extend into the lowest beds of limestone and the upper part of the greenstone. The contact surface, which here strikes about $\mathrm{N} 80^{\circ} \mathrm{W}$. and dips $23^{\circ}-40^{\circ} \mathrm{N}$., is displaced by a number of steeply dipping faults striking north to northeast. The amount of displacement ranges from a few inches to about 20 feet. A bed of gray shale 1 to 3 feet thick marks the limestone-greenstone contact.

The most promivent copper mineralization is along the contact of the limestone and greenstone at incline No. 1, and from incline No. 2 to tunnel No. 3, where the bed of shale and the upper 3 to 5 feet of greenstone contain evenly disseminated powdery malachite. The upper 2 or 3 feet of greenstone at these outcrops is weathered to a spongy mass. A few thin veins of malachite are in the limestone above 
the malachite-bearing shale. Some small pieces of chalcocite and bornite in limestone were found near one of the portals, but these minerals were not seen in place either on the surface or in the accessible underground workings. The scarcity of copper minerals in the material on the dumps suggests that no large bodies of these minerals were exposed by the underground workings.

\section{GREEN BUTTE MINE}

The Green Butte mine is on the east side of McCarthy Creek 11/2 miles north of the mouth of East Fork and 1,500 feet above the valley floor. (See pls. 26 and 27.) The upper Green Butte camp is near the portals of the upper mine levels at an altitude of 4,000 feet. The lower camp, on the east bank of McCarthy Creek at an altitude of 2,450 feet, is 11 miles from the town of McCarthy by the trail along MoCarthy Creek. The mine and upper camp may be reached from this trail by a foot trail starting at the lower camp or by a horse trail starting near the mouth of East Fork. Both trails are now difficult to follow because of rock slides and brush.

The original claims of the Green Butte property are believed to have been staked by J. E. Barrett, possibly in 1909 or earlier. The Green Butte Copper Co. later acquired the property and in the years 18:28 1925 drove about 14,000 feet of underground workings. The mine produced about 1,500 tons of high-grade copper ore during this period. Operations ceased in November 1925, and little or no development work has been done since then.

Nineteen lode claims and 4 mill sites (see pl. 27) belonging to the Green Butte property were patented in 1924 and are now held by John P. Satterfield and others. The two camps include a number of substantial buildings, most of which are in good condition, with living quarters for about 50. A tramway approximately 2,800 feet long extends from the lower camp to the main level of the mine. A considerable amount of mining equipment is left in the mine and at the camps.

Brief descriptions of the Green Butte mine and reports on the progress of development work are given in the annual reports on the mineral resources of Alaska for 1918 and for 1921 to 1930 inclusive. The more important of these are reports for 1922 and $1925 .^{7}$

The underground workings comprise 11,000 feet of drifts and crosscuts on 8 levels, 1,500 feet of inclines connecting the levels, and about 2,500 feet of raises, winzes, and stopes. The inclines and principal drifts and crosscuts are shown on plate 28. In 1943 the 500 -foot and lower levels, comprising about one-fifth of the mine, were flooded, and

\footnotetext{
${ }^{7}$ Brooks, A. H., and Capps, S. R., The Alaskan mining industry in 1922 : U. S. Geol. Survey Bull, 755, p. 27, 1924 ; Moffit, F. H., Mineral industry of Alaska in 1925: U. S. Geol. Survey Bull. 792, p. 28, 1927.
} 
eonsiderable portions of the 100 -foot and 400 -foot levels were inaccessible because of caving. Most of the raises, winzes, and stopes appeared to be open, but, with the exception of one stope below the 100fơot level, these were not examined by the writer.

The Green Butte patented lode claims extend along the contact between the Nikolai greenstone and Chitistone limestone from the vicinity of East Fork to McCarthy Creek. At the mine the limestone and greenstone strike N. $5^{\circ}-20^{\circ} \mathrm{W}$. and $\operatorname{dip} 10^{\circ}-25^{\circ} \mathrm{E}$. A bed of gray shale a few inches to 3 feet thick separates the greenstone and limestone. Significant quantities of copper minerals have been found only in the limestone, though some of the workings extend a short distance into the greenstone.

The principal copper mineral is chalcocite. Bornite, malachite, azurite, and covellite were seen in many specimens but constitute only a small percentage of the ore. The high-grade ore shipped to the smelter is reported to have averaged about 1,200 pounds of copper and about 10 ouncés of silver to the ton.

The copper minerals occur principally in vein-like bodies, which replaced the limestone along fractures and filled openings in the limestone. The localization of the vein deposits was controlled by steeply dipping fissures, which trend at a large angle to the strike of the limestone, and by bedding-plane faults. The most promising deposits seen were near the portal of the 100-foot level, where a few discontinuous veins and lenses of massive chalcocite having a maximum thickness of 3 or 4 feet are largely stoped out, and near the main incline on the 300-foot and 400-foot levels, where some chalcocite veins 6 inches to 2 feet thick are exposed. These veins appear to be discontinuous, either because they pinch out or because they are faulted, or for both reasons. Some of the steeply dipping faults are filled with white calcite containing thin veinlets of chalcocite and copper carbonates. The bed of shale at the contact and the limestone adjacent to the shale contain evenly disseminated malachite at several places in the mine.

Significant quantities of copper may still be present on the Green Butte claims, but the deposits seen in the accessible workings apparently are not large enough to justify the cost of establishing a means of transportation to the mine and reopening or extending the workings.

\section{TJOSEVIG PROSPECT}

The Tjosevig prospect is on the east side of McCarthy Creek, adjacent to the northernmost claims of the Green Butte group. (See pls. 26 and 27.) The area contains many cliffs, and some of it is therefore inaccessible.

The original claims were located by John Baultoff. In 1923 Neils Tjosevig restaked 8 lode claims, designated Big Ben lodes Nos. 1-6, 
Big Ben Extension lode mining claims Nos. 1 and 2, and Big Ben Mill site. (See pl. 27.) All the claims were patented in 1928 and are now owned by Mrs. Jean Tjosevig Jackson. Little or no work has been done on the prospect since the claims were patented.

The upper part of the Nikolai greenstone, the entire thickness of the Chitistone and Nizina limestones, and the lower part of the McCarthy shale, crop out in the cliff that forms the east wall of the valley of McCarthy Creek in the vicinity of the prospect. The beds strike about N. $45^{\circ} \mathrm{W}$. and $\operatorname{dip} 25^{\circ}-40^{\circ} \mathrm{NE}$. The lode claims include the outcrop of almost the entire thickness of the Chitistone limestone as well as the lower part of the Nizina limestone.

The copper minerals seen by the writer were malachite and azurite forming thin films and veinlets along fractures in the Chitistone limestone. A tunnel that starts in limestone talus on the Big Ben lode mining claim No. 3 was caved near the portal in 1943. The tunnel is probably less than 100 feet long, judging from the volume of the dump at the portal. The material in this dump showed little copper mineralization.

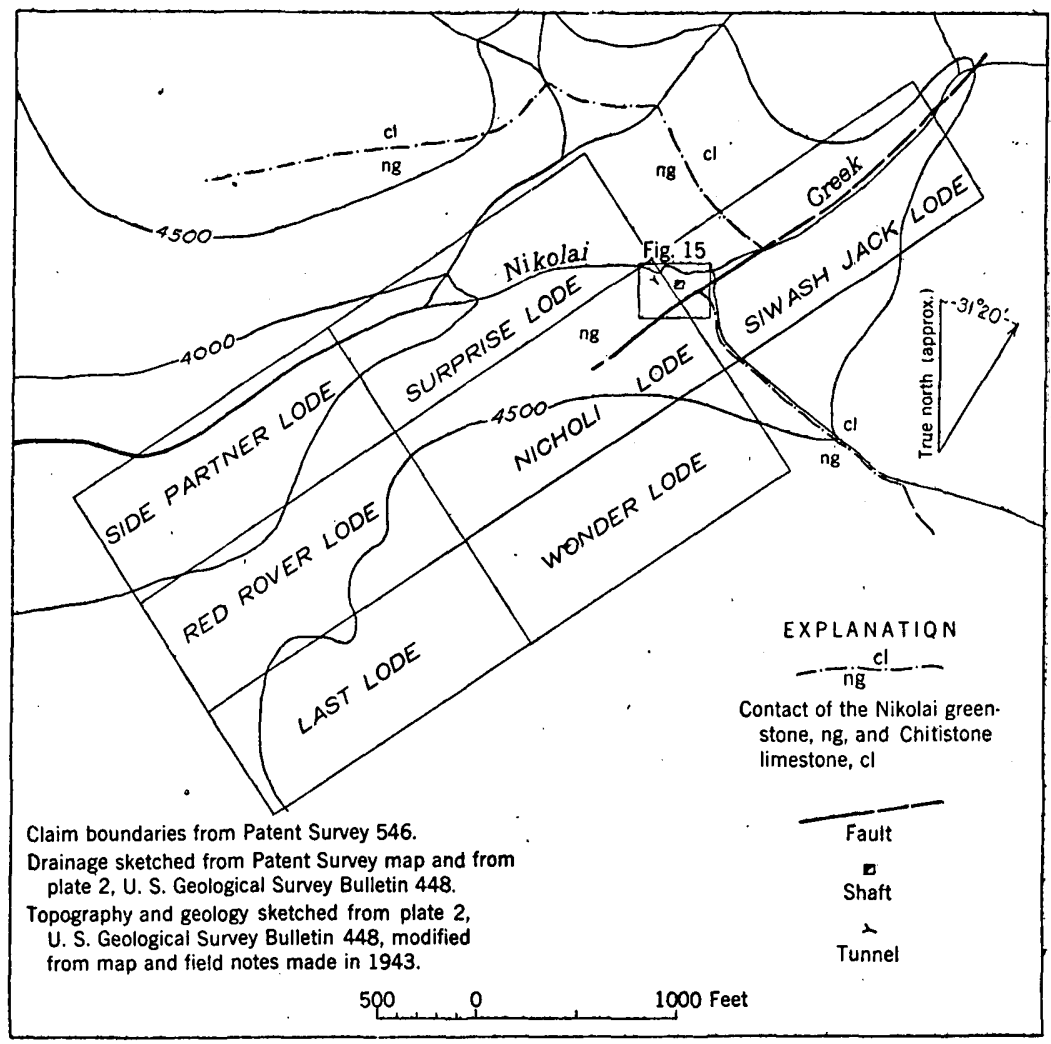

Figure 14.-Sketch map of the Nikolai patented claims. 
NIKOLAI MINE

The Nikolai mine is at an altitude of 4,250 feet on Nikolai Creek, $31 / 2$ miles from its junction with McCarthy Creek. (See pl. 26.) A horse trail leaves the McCarthy Creek trail at a point about 7 miles from McCarthy and follows Nikolai Creek to the mine. This trail has been used infrequently in recent years and in 1943 was difficult to follow, even on foot, because of brush.

The outcrop of copper minerals on Nikolai Creek was known to the Indians, one of whom revealed the location to Edward Gates in July 1899. The group of prospectors of which Gates was a member staked several claims and in 1900 did the development work necessary to obtain patent. In 1904 patent on 7 claims (see fig. 14) was granted to the Chittyna Exploration Co., the company formed by the prospectors. Most of the underground work was done in 1911, and so far as known to the writer this was the latest work done at the mine. No ore was produced.

The mine has been described by Schrader and Spencer ${ }^{8}$ and by Moffit and Capps. ${ }^{9}$ Underground surveys were made by engineers of the Kennecott Copper Corp. in 1929, but most of the workings were inaccessible in 1943.

The underground workings (fig. 15) comprise a shaft, now filled with ice a few feet from the collar, and a tunnel filled with ice at a point 30 feet from the portal. This tunnel extends 250 feet southeast from the portal and has 2 short drifts, one of which connects with the shaft about 55 feet below the collar. The depth of a winze in the southwestern branch of the tunnel is not known.

The geology and topography of the area in the vicinity of the Nikolai patented claims are shown in figure 14. Part of the area is shown on a larger scale on figure 15. The Nikolai greenstone and Chitistone limestone strike $\mathrm{N} .60^{\circ} \mathrm{W}$. and dip $30^{\circ} \mathrm{N}$. and are displaced about 150 feet (apparent vertical displacement) along a fault that strikes N. $50^{\circ} \mathrm{E}$. and dips $65^{\circ}-70^{\circ} \mathrm{S}$.

Copper minerals are present near the top of the greenstone in veins along two shear zones that lie north of the fault and at a low angle to it, and as thin veins and disseminated grains at some places in the greenstone adjacent to the shear zones. The fault, which can be traced for more than 2,000 feet along its strike, does not contain copper minerals at the surface.

Chalcopyrite and bornite are the principal copper minerals in the veins. Bornite is more abundant than chalcopyrite near the surface

\footnotetext{
${ }^{8}$ Schrader, F. C., and spencer, A. C., The geology and mineral resources of a portion of the Copper River district, Alaska : U. S. Geol. Survey Spec. Pub., pp. 86-87, 1901.

${ }^{\theta}$ Moffit, F. H., and Capps, S. R., Geology and mineral resources of the Nizina district, Alaska : U. S. Geol. Survey Bull. 448, pp. 93-95, 1911.
} 
but decreases downward, indicating that it was formed by surficial replacement of chalcopyrite. Small grains of secondary chalcocite are associated with the bornite. Malachite stains the copper sulfide minerals on exposed surfaces and along fractures. The primary copper mineral, chalcopyrite, filled open spaces and partly or completely

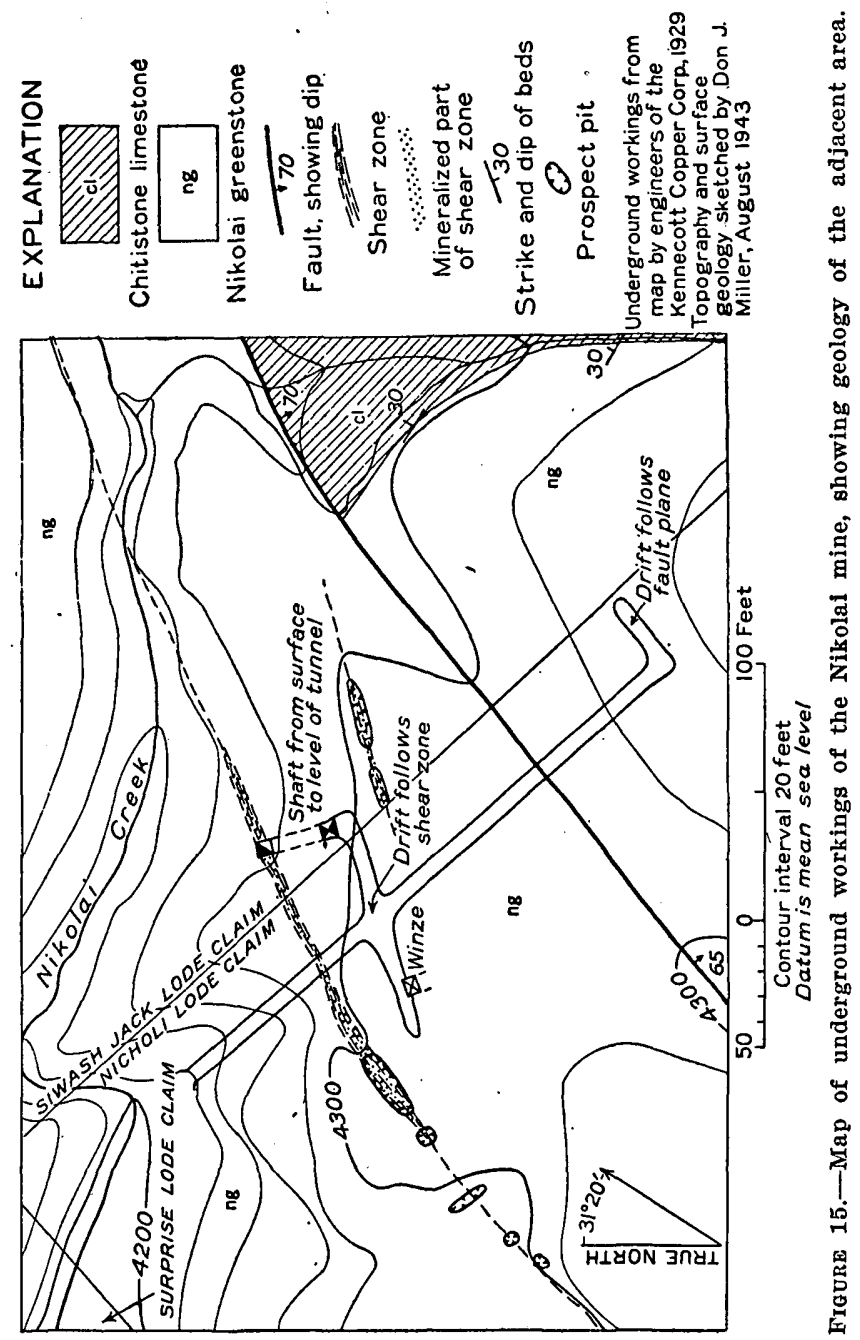

replaced sheared and fractured greenstone in the shear zones. Calcite, quartz, and epidote, chiefly as cavity fillings, are associated with the copper minerals. At least part of the quartz was deposited contemporaneously with chalcopyrite.

The northernmost shear zone, which strikes $\mathrm{N}$. $55^{\circ}$ E. and dips $55^{\circ}-75^{\circ} \mathrm{S}$., is the more highly mineralized. It is exposed for 600 feet along the strike, and through 150 feet of this distance it contains. 
a vein of copper and gangue minerals 1 to 4 feet thick. The shaft is sunk on this vein near its northeast end. According to the map made by engineers of the Kennecott Copper Corp. this vein is 6 to 12 inches thick and is exposed for 90 feet in the drift on the tunnel level.

The other shear zone, about 50 feet north of the fault, strikes N. $75^{\circ}$ E. and dips steeply south. It is exposed in shallow prospect pits for 50 feet along the strike and contains a discontinuous vein of bornite, chalcopyrite, and gangue minerals as much as 6 inches thick through most of this distance. This vein was not encountered in the tunnel, but the fault, which contains no copper minerals at the surface, shows copper stain on the tunnel level.

A small quantity of material, possibly 1,500 tons, containing 25 percent or more of copper, can be easily mined from the vein above the tunnel level in the northernmost shear zone, but this vein thins downward from the surface to the tunnel and probably wedges out a short distance below the tunnel. Although the vein exposed at the surface in the southernmost shear zone lies east of the tunnel, some evidence of mineralization would be expected in the tunnel if the vein extended to that depth. Since such evidence is lacking, it is assumed that this vein pinches out above the level of the tunnel. None of the many shallow prospect pits in the area adjacent to the exposed veins shows significant copper mineralization.

\section{WESTOVER PROSPECT}

The Westover copper prospect is on the east side of Boulder Creek, 1.6 miles north of the junction of Boulder and Dan Creeks. (See pl. 26.) The tunnels on the prospect are near the base of a cliff at altitudes of 4,740 to 4,875 feet, and 500 to 635 feet above a rock glacier at the head of Boulder Creek. A pack trail 3.3 miles long leads from the Dan Creek road at an altitude of 1,780 feet to the Westover camp site on the rock glacier below the tunnels. An extension of this trail to the lower tunnels has been partly destroyed by rock slides.

The Westover group was one of several groups of claims staked on Boulder and Dan Creeks about 1906 by the Alaska United Copper Exploration Co. The claims were later transferred to a subsidiary, the Alaska Westover Copper Co., and remained in the control of one of its officials, L. C. Dillman, after the companies were disbanded. H. D. Foster directed the development work. More than 1,400 feet of underground workings were driven from 1911 until the property was abandoned in 1930. Some ore was shipped.in the winter of 1917-18. In 1936 J. B. O'Neill restaked 6 cláims but little or no work was done on the prospect. In 1943 the claims were believed to be open for restaking. No equipment of value is left, and the one remaining cabin at the camp is not habitable. 
Brief descriptions of the Westover prospect were published by Moffit and Capps ${ }^{10}$ after a visit in 1909 before underground development was started, and by Moffit ${ }^{11}$ after a visit in 1916 when about 900 feet of underground workings had been completed.

The underground workings are principally on four levels (see pl. 29), not connected underground. All of the tunnel levels and raises and some of the winzes were accessible in 1943. The main workings are in tunnel No. 1 , which includes 680 feet of drifts and crosscuts, raises of 10,14, and 70 feet, a winze 10 feet deep, and 4 other winzes now filled with waste rock. Tunnel No. 2 comprises 245 feet of drifts and crosscuts and a 14-foot raise; tunnel No. 3 has. 245 feet of drifts and crosscuts and a short winze; and tunnel No. 4 has a 65 -foot drift and a winze filled with waste rock to within 9 feet of the top.

The Westover claims are in Chitistone limestone along its contact with the Nikolai greenstone. The rocks strike between N. $15^{\circ} \mathrm{W}$. and N. $25^{\circ}$ E. and $\operatorname{dip} 8^{\circ}-13^{\circ} \mathrm{E}$. A bed of gray shale as much as 3 feet thick is present between the two formations. In the vicinity of the tunnels the limestone and greenstone are cut by a number of steeply dipping faults, most of which strike north to northeast. The most prominent steep fault exposed in the tunnels has an apparent vertical displacement of about 20 feet. Several hundred feet south of the tunnels a similar fault displaces the limestone-greenstone contact at least 250 feet. Movement has also taken place between some of the limestone beds and along the limestone-greenstone contact. The displacement along the bedding faults is probably small. Most of the faulting took place before the copper minerals were deposited; but some of the displacement, at least along the steeply dipping faults, was later. At several places the limestone is fractured and recemented with white calcite.

The Westover deposit differs from most other deposits in limestone in the Nizina district in that bornite is the principal copper mineral. Chalcocite is evenly distributed through the bornite and apparently replaces it. Both minerals are partly oxidized to malachite. A small amount of chalcopyrite was found in specimens from tunnel No. 2.

The copper sulfide minerals are found in lenses, veins, and fracture fillings, and as disseminated grains in the lower 20 feet of the limestone. Calcite and quartz are the gangue minerals. Small pyrite crystals are scattered through the limestone. The deposition of the copper minerals apparently was controlled mainly by bedding faults, which caused the

${ }^{10}$ Mofftit, F. H., and Capps, S. R., Geology and mineral resources of the Nizina district, Alaska : U. S. Geol. Survey Bull. 448, pp. 95-97, 1911.

${ }^{11}$ Mofft, F. H., Mining in the lower Copper River basin : U. S. Geol. Survey Bull. 662, pp. 175-177, 1918. . 
replacement to be confined almost entirely to certain beds of limestone. To a lesser extent copper mineralization was controlled by some of the steeply dipping faults.

Mineralized limestone is exposed in three principal places in the underground workings (pl. 29). The first, at the portal of tunnel No. 1 , constituted the discovery body. Copper minerals were exposed in a wedge-shaped body 35 feet long and 10 feet high at the south end where it consisted of massive bornite and chalcocite. ${ }^{12}$ At the north end the bornite and chalcocite graded into silicified limestone. Tunnel No. 1 is driven on the south end of this body, which was restricted to the 2 lowest beds of limestone, each about 6 feet thick, and extended about 35 feet down the dip of the beds. Most of the body has been mined. A second mineralized body in the same limestone beds is penetrated by tunnel No. 1 at a prominent fault 65 feet from the portal. This body, which has a maximum width of about 40 feet and extends 55 feet eastward from the fault, also has been largely mined out. Nearly flat veins of massive bornite and chalcocite as much as 2 feet thick are exposed on the north and south walls of the main drift, east of the raise, but as shown by the crosscuts these extend into the walls only a few feet.

The third mineralized limestone body is exposed in the southern crosscut in tunnel No. 3. Here a 5 -foot bed of limestone that is believed to be about 15 feet above the greenstone contains disseminated malachite and copper sulfide minerals and a few small lenses of massive bornite and chalcocite. A nearby pile of ore, estimated to weigh about 10 tons and to contain about 30 percent of copper, probably was mined from this place.

Only thin stringers and disseminated grains of copper minerals were seen in tunnel No. 2 and tunnel No. 4.

It is estimated that about 100 tons of material containing about 30 percent of copper and an equal amount containing about 10 percent of copper can be mined from the exposed bodies. The showings underground and on the surface in the vicinity of the prospect give little reason to expect that bodies larger than or even similar in size to those already exposed may be found on the Westover claims.

\section{NELSON PROSPECT}

The Nelson prospect is on the south side of Glacier Creek 1 mile from its junction with Chitistone River, and approximately 11 miles by foot trail or horse trail from the road at Dan Creek. (See pl. 26 and fig. 16.) A wide trail extends from the camp at an altitude of 2,400 feet on the south bank of Glacier Creek to the tunnels at altitudes of 2,850 to 2,955 feet on the bluff above the creek.

\footnotetext{
${ }^{12}$ Moffit, F. H., Mining in the lower Copper River Basin: U. S. Geol. Survey Bull. 662,
} p. 176, 1918. 
The copper showings were discovered in 1928 by C. A. Nelson, who located a number of claims and sunk several prospect pits on the mineralized outcrops. In 1929 the prospect was taken under option by the Kennecott Copper Corporation, and development work, including the construction of about 1,100 feet of exploratory tunnels, was carried on until July 1930 when the prospect was returned to the owner because the development work failed to disclose a quantity of ore considered sufficient to justify further expenditure. In driving the tunnels some.ore was mined and part of it is reported to have been shipped. The owner continued assessment work and in 1935 patented 6 claims. (See fig. 16.) In addition to the patented claims, Mr. Nelson held one unpatented claim, the Cascade Quartz lode claim, in 1943. There are 4 substantial $\log$ buildings on the Cascade Quartz claim and 2 small sheds at the tunnels. Some mining equipment is left on the claims.

The Nelson prospect has been described by Bateman, ${ }^{13}$ who dealt principally with the ore minerals, and by Pilgrim, ${ }^{14}$ who dealt principally with the underground workings.

The underground workings at the Nelson prospect comprise 5 tunnels on 4 levels. (See fig. 17.) In 1943 the workings were accessible, except for about 50 feet of tunnel No. 2, most of tunnel No. 3, and about half of tunnel No. 4, which were inaccessible because of caved roofs. Most of the prospect pits dug in the soil and broken rock to expose bedrock were slumped.

The copper deposit is in the lowest beds of a block of Chitistone limestone more than a mile long and 2,000 feet wide, which has been faulted down in relation to the main mass of limestone about 3,000 feet higher in the mountain to the south. (See fig. 16.) The fault plane dips southwest, and the limestone and greenstone on the southwest side are thrust over the corresponding beds on the northeast side. This is one of the major faults in the Nizina district. It has been traced to the northwest beyond Nizina River, and probably extends to the southeast up the valley of Glacier Creek. The limestone block is also cut by many steeply dipping faults of small displacement, most of which make a large angle to the major fault. At the tunnels the Chitistone limestone strikes N. $5^{\circ}-25^{\circ} \mathrm{W}$. and dips $10^{\circ}-15^{\circ} \mathrm{SW}$. The lowest tunnel, No. 1, intersects the limestone-greenstone contact. At this tunnel a 5 -foot bed of brown and green shale separates the limestone and greenstone. Some of the beds of limestone in the higher tunnels are dolomitic.

\footnotetext{
${ }^{13}$ Bateman, A. M., Notes on a Kennecott type of copper deposit, Glacier Creek, Alaska : Econ. Geology, vol. 27, No. 3, pp. 297-306, 1932.

14 Pilgrim, E. R.. In mining investigations and mine inspection in Alaska, biennium ending March 31, 1933 [report of Alaska Supervising Mining Engineer], pp. 88-90, 1933.
} 


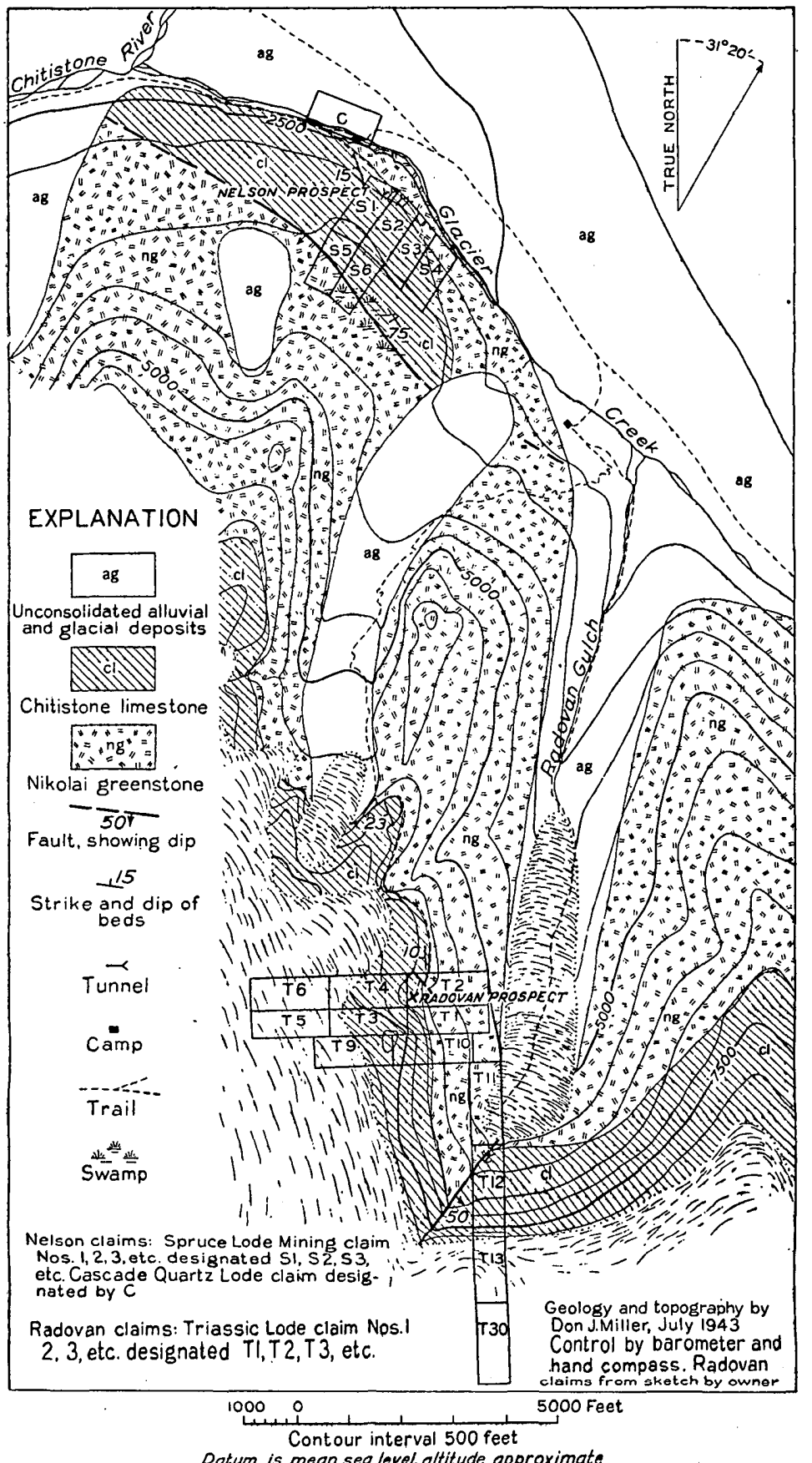

FIGURE 16.-Geologic sketch map of the vicinity of the Nelson and Radovan copper prospects. 


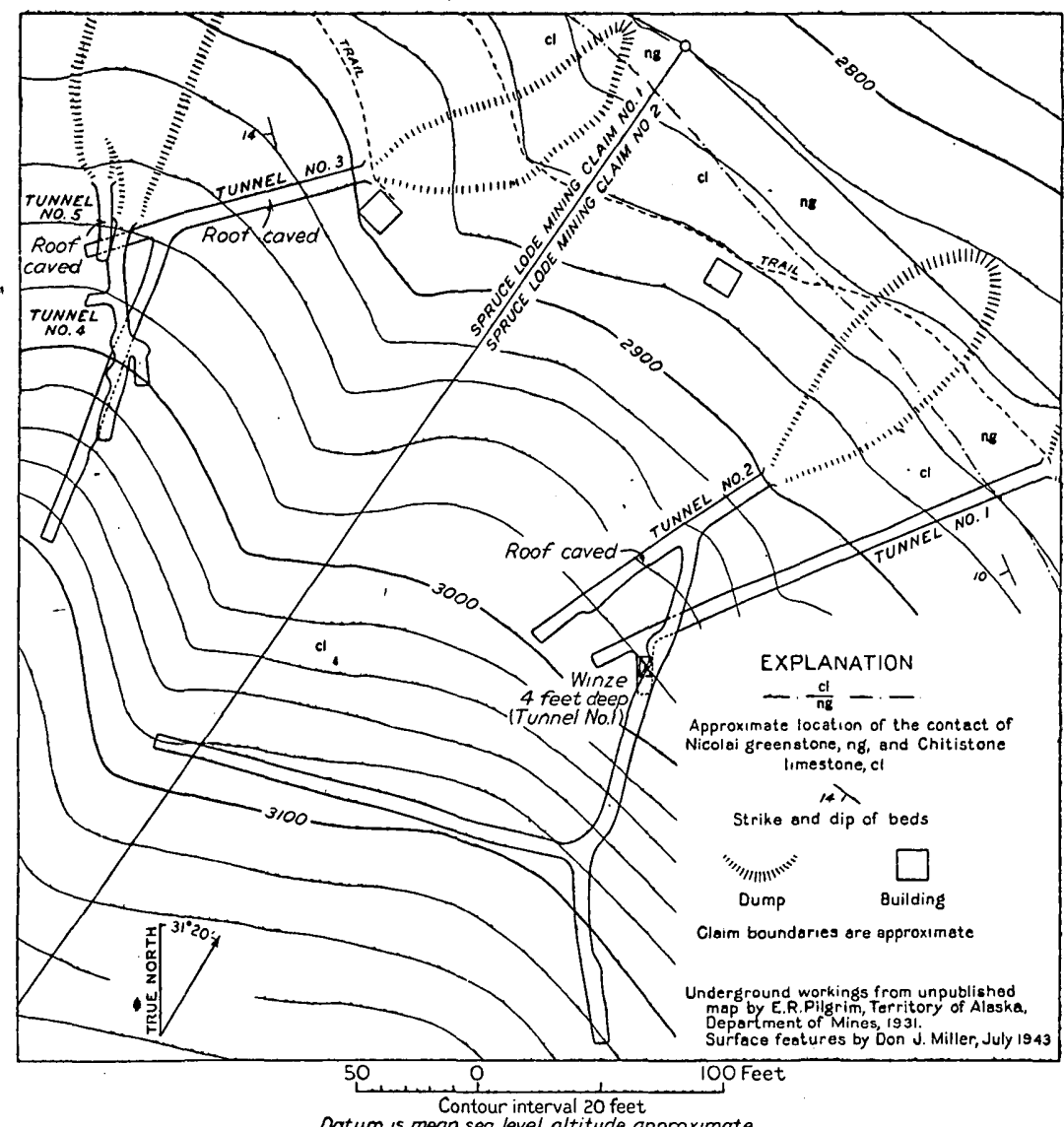

Figore 17.-Map of underground workings at the Nelson prospect, showing geology of the adjacent area.

Chalcocite and covellite are the principal copper minerals. ${ }^{15}$ Enargite, bornite, malachite, chalcopyrite, and pyrite are present in small amounts. Calcite and dolomite are the only gangue minerals. The copper minerals filled openings in the limestone and replaced it along bedding planes and steeply dipping fissures, forming veins, bunches, thin stringers, and disseminated grains.

The most promising deposits encountered in the exploratory work by the Kennecott Corp. were in tunnels Nos. 1, 2, and 4. Several tons of nearly pure chalcocite and some lower-grade material were mined from a 4-foot winze near the southwest end of tunnel No. 1 where copper minerals partly replaced the basal bed of Chitistone limestone along the hanging wall of a fault having a displacement of about 20 feet.

2s Bateman, A. M., op. cit., pp. 300-301, 1932. 
The southward-trending branch of tunnel No. 2 was driven along a steeply dipping vein of copper minerals half an inch to several inches thick. This vein averages about 1 inch in thickness over a distance of 100 feet along the tunnel, and if its height is assumed to be equal to its length, the vein may contain about 130 tons of material with 60 percent or more of copper. A few tons of high-grade ore are reported to have been mined from this vein. Tunnel No. 4 was driven along the strike of a steeply dipping chalcocite-covellite vein that is $1 / 4$ inch to 5 inches thick and averages about $11 / 2$ inches over a distance of 30 feet. Assuming that its height is equal to its length this vein may contain about 18 tons of material with 50 percent or more of copper. Only a small quantity of copper minerals was found in tunnels Nos. 3 and 5.

\section{RADOVAN PROSPECT}

The Radovan claims cover an area of cliffs and glaciers at the head of a short, cirque-like valley known locally as Radovan Gulch, which extends into the valley of Glacier Creek 2 miles from its junction with the Chitistone River. (See pl. 26 and fig. 16.) Radovan's camp near the mouth of the gulch is reached from the road at Dan Creek by the foot trail or horse trail along the Nizina and Chitistone Rivers and Glacier Creek, a distance of about 13 miles. Hand-powered tramways are used where the foot trail crosses Glacier Creek. A foot trail 3 miles long leads from the camp at an altitude of 2,600 feet to the prospect at an altitude of about 6,340 feet on the west side of Radovan Gulch. The upper part of this trail follows a narrow bench developed on the shale at the limestone-greenstone contact, far above the bottom of the gulch. A second trail leads along the bottom of the gulch to another prospect at its head.

The malachite stain covering the outcrop of copper minerals at the prospect was seen from the bottom of the gulch many years ago and was called the "binocular prospect." The outcrop was thought to be inaccessible until Radovan discovered a means of reaching it in 1929. He staked 30 claims in the gulch in 1929-31 and was holding 12 of them in 1943. (See fig. 16.) The development work at the main prospect consists of several shallow pits on the mineralized outcrop. Two exploratory tunnels totaling more than 100 feet were driven at the head of Radovan Gulch but no significant quantity of copper minerals was found there.

The Radovan prospect was described by Pilgrim ${ }^{16}$ following his inspection of the property in 1931, when only part of the outcrop was accessible. Mr. Radovan accompanied the writer on visits to the main prospect and to the tunnels at the head of Radovan Gulch.

${ }^{16}$ Pilgrim, E. R., op. cit., pp. 90-92, 1933. 
More than 5,000 feet of Nikolai greenstone and Chitistone limestone are exposed in the cliffs around Radovan Gulch. On the west side of the gulch the rocks strike N. to N. $25^{\circ} \mathrm{W}$. and $\operatorname{dip} 10^{\circ}-25^{\circ}$ W. On the east side the strike is more nearly northwest and the dip is $20^{\circ}$ or more to the south. A thin bed of gray shale separates the limestone from the greenstone. A steep narrow indentation in the cliffs at the head of the gulch marks the position of a fault that strikes N. $40^{\circ} \mathrm{E}$. and dips about $50^{\circ} \mathrm{S}$. The limestone-greenstone contact east of this fault is 1,000 feet lower than the contact west of the fault. A small dike of highly altered igneous material is exposed along the lower part of the fault.

The Radovan prospect is in a lens of fractured dolomitic limestone, which crops out for several hundred feet along the west side of the gulch. This lens, with a maximum thickness of 90 feet, forms a bench between vertical cliffs of underlying and overlying limestone that is more resistant. The top of the lens is 200 feet above the base of the Chitistone limestone. About 400 feet north of the prospect a normal fault that strikes N. $45^{\circ} \mathrm{W}$. and dips $70^{\circ} \mathrm{S}$. displaces the limestone beds 25 feet or more. The top of the mineralized lens is separated from the overlying massive limestone by a well-defined bedding fault.

The primary metallic minerals at the prospect, in probable order of decreasing abundance, are pyrite, marcasite, chalcocite, bornite(?), and chalcopyrite. These minerals occur in massive lenses, thin veins, fracture fillings, and as disseminated grains in the upper 20 feet of the dolomitic limestone lens for a distance of 200 feet along the outcrop. A considerable amount of limonite and some malachite, azurite, and cuprite(?) have been produced by the oxidation of the sulfide minerals. The gangue minerals are calcite, dolomite, and quartz.

At the south end of the mineralized outcrop a prospect pit 5 feet deep exposes a lens 1 to 3 feet wide and 6 feet long, composed mainly of pyrite, quartz, and marcasite. A similar but smaller lens is exposed in a pit 20 feet farther north. Chalcocite occurs in these lenses, but analysis of a chip sample taken across the larger lens shows only 0.03 percent of copper ${ }^{17}$ and no gold or silver..$^{18}$ Fifty feet north of the southernmost prospect pit is a nearly vertical fissure 6 to 12 inches wide and about 15 feet long, filled with limonite and copper oxide and carbonate minerals. This material is reported to contain about 12 percent of copper. The discovery outcrop, about 125 feet north of the southernmost prospect pit, consists of iron and copper sulfide minerals which have replaced dolomitic limestone and filled

17 Analysis by Esther Claffy, Geological Survey.

${ }^{18}$ Assay by Samuel H. Cress, Geological Survey. 
fractures in it. A shallow pit driven in this outcrop exposes a lens 6 by 5 by $11 / 2$ feet, consisting of pyrite with some chalcocite and marcasite. Analysis of a chip sample taken across 10 feet of the mineralized limestone, including the 6-foot lens, indicates a copper content of about 4 percent, although a few small patches contain at least 25 percent. The northernmost prospect pit is driven in limonite-stained dolomitic limestone where malachite and azurite have developed in thin films along fractures.

The lens of fractured dolomitic limestone is accessible for several hundred feet north of the prospect but shows only scattered copper stains. The part of the lens south of the southernmost prospect pit is not accessible, but no copper stain can be seen in it from a distance of a few hundred feet.

The mineralized outcrops at the Radovan prospect apparently do not contain a significant quantity of copper, though they may indicate the presence of copper-bearing material of higher grade at depth.

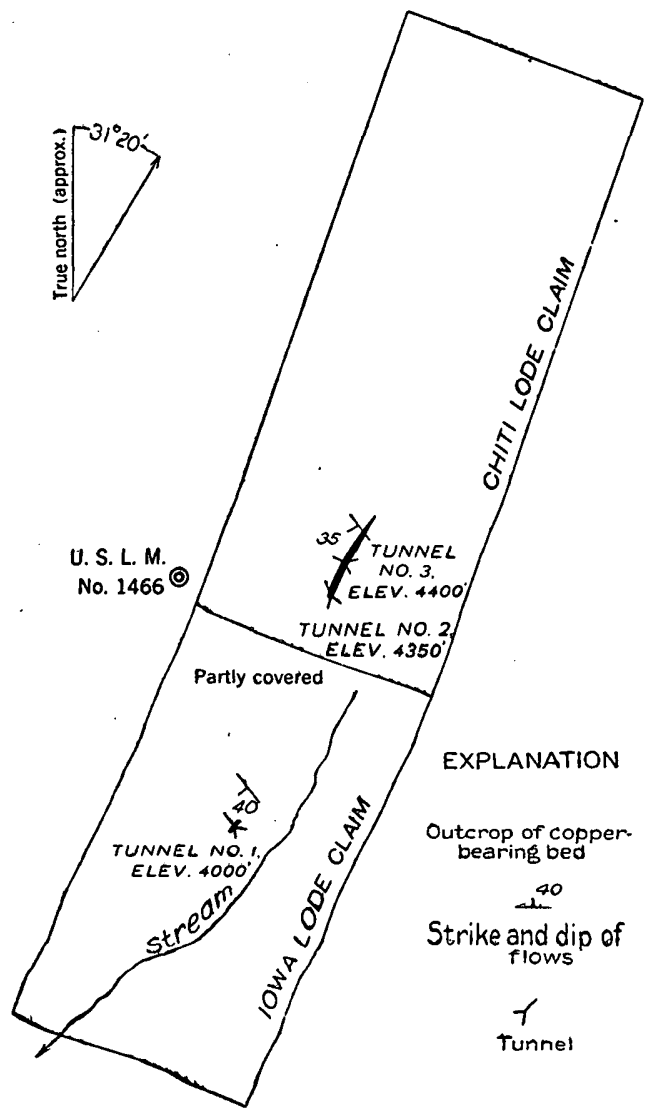

Claim boundaries and tunnels from Mineral Survey 1466 1000 500 Feet

Figure 18.-Map of patented claims at the Erickson prospect. 
This is considered unlikely, however, since the principal minerals are pyrite and marcasite.

\section{ERICKSON PROSPECT}

The Erickson prospect is on the northeast side of the valley of Glacier Creek about 1 mile east of the head of the creek. (See pl. 26.) The tunnels are on the west side of a small gulch at altitudes of about 4,000 to 4,400 feet and are 200 to 600 feet above the surface of a glacier. The prospect is about 16 miles from the road at Dan Creek by way of the trial along the Nizina and Chitistone Rivers and Glacier Creek. The trail is not suitable for horses beyond the lower end of the glacier.

Indians discovered and used the native copper on Glacier Creek before white men came to the Nizina district. The original claims were staked in 1906 by Peter Erickson and George Madden. A few hundred feet of underground workings were driven, and in 1917 some ore was shipped. Two claims (see fig. 18), patented in 1927, were owned in 1943 by James McGavock and Fred Erickson.

Moffit and Maddren ${ }^{19}$ inspected the Erickson prospect in 1907 before underground development work was started. Martin F. Radovan accompanied the writer on a visit to the prospect in 1943.

The underground workings total more than 300 feet distributed on 3 levels. Tunnel No. 1, driven in the lowest outcrop of the copper. bearing bed, was caved at the portal in 1943. It is reported to be about 100 feet long. The main workings are in tunnel No. 2 (see fig. 19) in

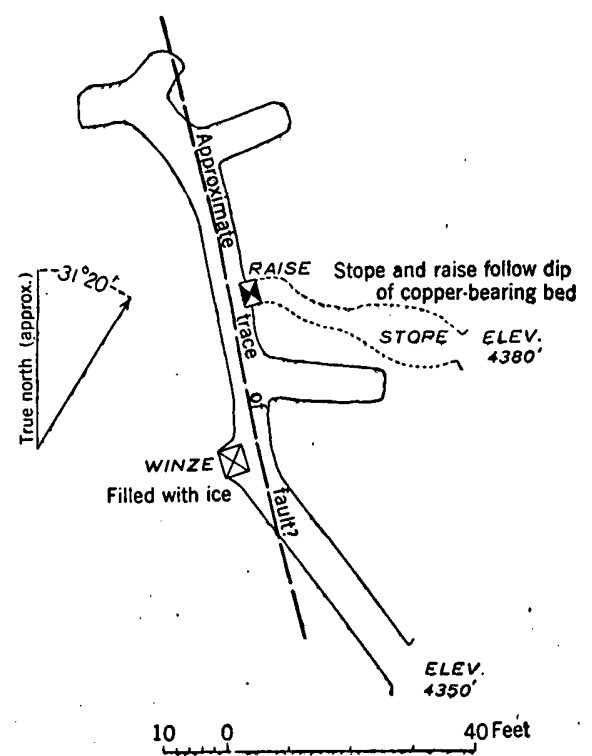

FigUke 19.- Sketch map of tunnel No. 2, Erickson prospect.

${ }^{10}$ Moffit, F. H., and Maddren, A. G., Mineral resources of the Kotsina-Chitina region, Alaska: U. S. Geol. Survey Bull. 374, pp. 90-91, 1909. 
which are 155 feet of drifts and crosscuts, a raise and a stope along the mineralized bed from the main level to the surface, and a winze reported to be about 55 feet deep and to have a short drift at the bottom. The winze was filled with ice in 1943. The main drift in tunnel No. 2 apparently follows a steeply dipping fault that displaces the copperbearing bed out of the level of the tunnel. The drift at the bottom of the winze may be in the displaced portion of the bed. Tunnel No. 3 is 12 feet long and is driven on an outcrop of the black amygdaloidal bed cut by veins of quartz that contain a little native copper.

Nikolai greenstone forms the northeast wall of the valley of Glacier Creek and extends for several miles east of the lower end of the glacier. The greenstone exposed in the gulch at the prospect includes a succession of amygdaloidal flows which strike northwest and dip $35^{\circ}-40^{\circ}$ SW. The greenstone is extensively faulted, but the amount of displacement is difficult to determine because the beds cannot be differentiated. The copper minerals apparently are restricted to one of the flows, a 6- to 8-foot bed of greenstone filled with black amygdules. This bed is exposed on the west side of the gulch for about 20 feet at the portal of tunnel No. 1 , and for about 225 feet northeast from tunnel No. 2. (See fig. 18.) Part of the area between tunnel No. 1 and tunnel No. 2 is covered with slide rock, but where the greenstone is exposed the copper-bearing bed was not recognized.

Native copper is the principal copper mineral in the amygdaloidal bed. It forms irregularly shaped masses, thin veins, and stringers in the greenstone, also small grains disseminated in the greenstone and in black amygdules. Masses of native copper weighing up to 60 pounds have been found, but most of the copper is in small grains. Associated with the native copper are chalcocite, malachite, and cuprite. The black amygdules are a mixture of carbonaceous material and black copper oxides. Quartz is associated with the copper minerals as a filling in amygdules and as veins.

The black amygdaloidal bed is estimated to have an average copper content of less than 5 percent, though some parts of the bed may contain as much as 10 percent. The copper-bearing bed would be difficult to follow, because of faults, and mineralization in it is likely to be discontinuous.

\section{OTHER PROSPECTS}

The limestone-greenstone contact in the Nizina district was staked at many places as copper-bearing ground, but many of the claims showed little or no evidence of copper mineralization and were soon abandoned. A number of prospects on Hidden Creek, Fourth of July Creek, Dan Creek, and the Chitistone River are described in reports by Moffit and others. Brief reference will be made to these prospects, 
though only the Snow Bird group of claims on Dan Creek and the Peavine prospect on the Chitistone River were visited by the writer in 1943.

\section{HIDDEN CREEK AND FOURTH OF JULY CREEK}

Hidden Creek occupies a narrow steep-walled valley on the west side of Kennicott Glacier about 10 miles northwest of McCarthy. (See pl. 26.) Fourth of July Creek occupies a more open valley about 4 miles south of Hidden Creek. An abandoned trail leads along the west side of Kennicott Glacier from the railroad to the Hidden Creek prospect with a branch along Fourth of July Creek.

The Nikolai greenstone, Chitistone limestone, and McCarthy shale are exposed along Hidden Creek and at the head of the north fork of Fourth of July Creek. The greenstone contains bornite, chalcopyrite, chalcocite, and other copper minerals at several places along both creeks.

Claims were first staked along the limestone-greenstone contact on Hidden Creek and Fourth of July Creek in 1906, by the Great Northern Development Co. and the Valdez Exporation Co. ${ }^{20} \cdot$ Development work was continued on some claims until 1920 or later, on Fourth of July Creek principally by Woodin and Herman, and on Hidden Creek by the Tjosevig Bros. and the Josevig-Kennecott Corp. ${ }^{21}$ A little ore was shipped from the Fourth of July. Creek claims.

\section{DAN CREEK}

The north side of the valley of Dan Creek is composed largely of Nikolai greenstone and Chitistone limestone; their contact lies 2,000 to 4,000 feet above the valley floor. The beds strike nearly parallel to the valley and dip north at a low angle. Copper minerals, including bornite, chalcopyrite, chalcocite, and native copper, have been found in the greenstone at many places along the north side of the valley.22 They are particularly common in a zone about 30 feet below the base of the Chitistone limestone but have not been found in significant quantities in the limestone, except at the Westover prospect (see pp. 108-110). Nuggets of native copper derived from the greenstone are found in the placer gravel on Dan Creek and some of its tributaries. A copper nugget estimated to weigh about 3 tons was found. in Dan Creek in 1939.

${ }^{20}$ Moffit, F. H., and Maddren, A. G., Mineral resources of the Kotsina-Chitina region, Alaska: U. S. Geol. Survey Bull. 374, pp. 77-80, 1909.

${ }^{21}$ Moffit, F. H.. Mining in the lower Copper River Basin: U. S. Geol. Survey Bull, 662, pp. 162-163, 1918.

${ }^{2}$ Mofft, F. H., and Capps, S. R., Geology and mineral resources of the Nizina district, Alaska : U. S. Geol. Survey Bull. 448, p. 97, 1911; Moffit, F. H., op. cit. (Bull. 662), pp. 175-177, 1918. 
In addition to the Westover claims, the Alaska United Copper Exploration Co., or its subsidiary the Alaska Westover Copper Co., held the Snow Bird, Bear Paw, and Golden Eagle groups of claims (see pl. 26) in the vicinity of Boulder Creek. Development work on these claims includes at least three short tunnels in the greenstonetwo on the Snow Bird group and one on the Golden Eagle group. Other copper claims, the exact sites of which are not known, were located on Dan Creek by the Dan Creek Gold and Copper Co. and the Nikolai Butte Copper Co.

The only copper production reported from Dan Creek is from the Westover prospect and from gold placer operations which have yielded about 40 tons of native copper as a byproduct.

\section{CHITISTONE RIVER}

Copper minerals occur in both the Nickolai greenstone and the Chitistone limestone, which crop out on both sides of the Chitistone River from its mouth to the vicinity of Glacier Creek. Beyond Glacier Creek the greenstone alone forms the valley walls for about 5 miles. ${ }^{23}$

The Houghton Alaska Exploration Co. owned copper claims along the limestone-greenstone contact north of the Chitistone River opposite the mouth of Glacier Creek, and south of the river, 2 miles below. the mouth of Glacier Creek. (See pl. 26.) The Alaska United Copper Exploration Co. owned claims in the vicinity of a gulch known locally as Contact Gulch, north of the junction of the Chitistone River and Glacier Creek. No large deposits of copper minerals were found, and the claims were abandoned by the original owners about 1920. In 1921 William Mahar restaked 6 claims at the site of the Houghton Alaska claims south of the Chitistone River. These claims, called the Peavine prospect, were abandoned in 1938. No copper was shipped from the prospects on the Chitistone River.

\footnotetext{
${ }_{23}$ Moffit, F. H., and Maddren, A. G.; Mineral resources of the Kotsina-Chitina region, Alaska: U. S. Geol. Survey Bull. 374, pp. 89-90, 1909.
} 